\title{
Zooplankton Research in Lake Kinneret: A Review
}

\author{
Moshe Gophen* \\ Migal Scientific Research Institute, POB 831, POB 831 Israel-11016 \\ ${ }^{\star}$ Corresponding author: Dr. Moshe Gophen, Migal Scientific Research Institute, Kiryat Shmone, POB 831, POB 831 Israel; Tel: +505 399 540; E-mail: Gophen@Migal.org.il \\ Received: September 15, 2021; Accepted: September 22, 2021; Published: September 27, 2021 \\ "As far as the laws of mathematics refer to reality, they are not certain, and as far as they are certain, they do not refer to reality" (A. Einstein).
}

\begin{abstract}
The ecological status of the zooplankton compartment and its complex interactions in Lake Kinneret are here reviewed with respect to regional climate change. Food web and thermal structure modifications resulting from climate change affected the zooplankton community. Nutrient dynamics and the structure of phytoplankton assemblages were modified. The dominant representative genus Peridinium of the Pyrrhophyta was replaced by Cyanobacteria, accompanied by Bacillariophyta and Chlorophyta proliferation. As a result of limitation constraints on the fish market, the Bleak (Mirogrex terrae-sanctae, Acanthobrama lissneri) stock in the lake was enhanced, with resulted in a decline in zooplankton biomass. The zooplankton biomass reduction could be attributed to the top-down cascading enhanced pressure which, together with the increase in Total Phosphorus, resulted by climate change as a result of internal and external impact conditions, supported the increase in nano-phytoplanktonic biomass.
\end{abstract}

Keywords: Kinneret, Zooplankton, Cyanobacteria, Bleak, Climate Change

\section{Introduction}

Lake Kinneret is a warm monomictic lake which is the only one natural freshwater lake located below sea level in Israel. Enclosed some Hydro-Morphometrical information of Lake Kinneret under maximum permitted Water

Level- 208.8 meter below sea level (mbsl)

Water level fluctuation: $214.87-208.20 \mathrm{mbsl}$

Water surface area - $169.5 \mathrm{Km}^{2}$

Maximum depth - $48 \mathrm{~m}$

Altitude of deepest bottom area - 256 mbsl

Mean depth - $26 \mathrm{~m}$

The ratio between mean and maximum depths - 0.54

Total Lake Volume - $4.471 \mathrm{~km}^{3}$

Shore line length - $55 \mathrm{~km}$

Lake Maximum length - $21 \mathrm{~km}$

Lke Maximum width - $12 \mathrm{~km}$

D value for Lake Kinneret - 1.19

$\mathrm{D}$ value is the ratio between actual shoreline length and perimeter of geometric cycle which has the same area of the lake.

The food web structure in Lake Kinneret, like in any other lake, comprises of different compartments, including a zooplankton compartment. Nevertheless, not as commonly considered, the role of each has different impact in the food-web. The status of each natural compartment of a system is related to its quantitative significance, surplus, deficiency or sufficiency level. The optional capability of significant anthropogenic successful management depends on thorough knowledge of the eco-physiological features of each compartment. Management achievement is rated by water quality. This is the concept of Kinneret zooplankton research in the past, present and for the future. The far history approach to zooplankton research was mostly based on taxonomy, physiology, diurnal vertical migration and spatial bathymetrical distribution, as well as fish and invertebrate predation densities. Nevertheless, future perspectives on zooplankton research are aimed at its status within the entire food web structure. Moreover, modeling development defines the impact of zooplankton on the flow pattern of energy, carbon or any other key element throughout the food web structure.

The recent 20 years represent changes in climate conditions accompanied by modifications in nutrient dynamics and the phytoplankton community structure in the lake and its drainage basin. Modification or additional research approaches such as a change of the routine methods might be resulted by loose of informative data and continuity of the record. Therefore, deviation from the routine methodology of zooplankton research might cause cut of data flow between past and present which are critical for future studies and require comparative indications.

\section{Background}

Features of Lake Kinneret and its drainage basin are given partly given here but widely presented in [1-4]. Lake Kinneret, the only natural freshwater lake in Israel, is a warm Monomictic lake which is stratified from May through mid-December (anoxic Hypolimnion) and totally mixed from mid-December through April. Due to its high temperature of seasonal and Bathymetrical mean range of 
$15-33^{\circ} \mathrm{C}$, the thermal stratification is stable and separates the lake into two thermal compartments of Epilimnetic 0-20 m depth and Hypolimnetic thickness $24 \mathrm{~m}$ (20 m - bottom). The Epilimnion is rich in oxygen and poor in other nutrients. Oxygen is completely absent in the Hypolimnion, which is rich in ammonia, sulfides and $\mathrm{CO}_{2}$. Due to the stability of the thermal structure, there is a steep gradient of substances in the thin Metalimnion layer, indicating a slow rate of nutrient exchange between the Epilimnetic and Hypolimnetic layers [3-4].

Regional climate conditions of temperature and precipitation ranges are subtropical with high levels in winter and low in summer. The high difference between summer and winter temperatures create separation between the Epilimnion and the Hypolimnion, resulting reductive and anoxic Hypolimnetic waters. As a result during the summer stratification period there are high concentrations of dissolved Phosphorus, Ammonium, Sulfides and $\mathrm{CO}_{2}$ in the Hypolimnion whilst deficiency of nutrients in the Epilimnion.

\section{The Lake Kinneret Watershed}

The hydrological management of the Lake Kinneret volume capacity and, consequently, water level (WL) is a rainfall regime dependent and the demands for water supply. The amplitude of WL fluctuation is a legislated limit of 208.80-213.00 meters below sea level (MBSL) but actually the amplitude was larger. The Lake Kinneret ecosystem has undergone significant changes during the last 70 years of the Anthropocene Era. Anthropocene period is dating from the commencement of human impact on the ecosystem; approved (March 2021) by International Commission on Stratigraphy (ICS) and International Union of Geological Sciences (IUGS). Some of the changes include: water level changes within $6.7 \mathrm{~m}$ amplitude, high range of inflow discharges between $>10^{9} \mathrm{~m}^{3}$ and $<260 \times 10^{6} \mathrm{~m}^{3}$ per annum, precipitation range of 333-1060 mm/y, and changes in fish stock, Epilimnetic temperatures, phytoplankton density and species composition, zooplankton biomass density and body size composition, and nutrient concentrations [4]. The high numerical density of small Rotifera (>100 Ind./l) [5-15] in Lake Kinneret in winter is the result of river floods containing reservoir and fishpond effluents with also Cladocera (Daphnia spp.), and the counterpart Copepoda (Eucyclops serrulatus) and Diaptomida (Eudiaptomus gracilis) which are intensively preyed upon by fish at the river mouth region. Zooplankton predators accumulate within the river mouth zone and therefore, the densities of large body zoopllanktonic organisms in the lake pelagial is extremely low ( $<5$ ind./l) [15]. River floods in winter enrich the lake fauna mostly with small rotifers.

The concept of this paper is re-evaluation of zooplankton status under the recent climate and anthropogenic changes within the complex interaction of the Lake Kinneret food web. An attempt is made at predicting how natural and anthropogenic environmental changes influence the zooplankton status.

\section{Historical (1969-2020) Remarks on the Kinneret Zooplankton Research [Biomass Decline: $>50$ to $\left.<20 \mathrm{~g}(\mathrm{ww}) / \mathrm{m}^{2}\right)$ ]}

The continuity of zooplankton research in Lake Lake Kinneret was slightly modified beyond the 2000 `s when the increase of small size organisms was recorded. The zooplankton research prior to the 2000's is considered as a cornerstone of Lake Kinneret limnological research. In the early 2000s, annual reports of both biomass $\left(\mathrm{g}(\mathrm{ww}) / \mathrm{m}^{2}\right)$ and numerical data $(\mathrm{No} / \mathrm{L})$ were published. The routine monitoring data that were published annually during 2003-2005 by the Kinneret Limnological Laboratory (KLL) of the Israel Limnological and Oceanographic Research Company Ltd (IOLR) [1] included information on total zooplankton biomass density within the range of $20-24 \mathrm{~g}(\mathrm{ww}) / \mathrm{m}^{2}$, which is similar to earlier common ranges reports. Later on enhancement of increasing portion of small organisms was reported. The contribution of the biomass of Rotifera was much higher, contributing $15-43 \%$ of the total biomass, with Cladocera contributing $35-53 \%$. Such a difference might be due to the change in the routine of sampling programs, as well as sorting and microscopic counting technologies. The long-term trend in changes, either expressed as numerical data or biomass, was confirmed and analyzed as mostly affected by Bleak [Mirogrex terraesanctae terraesnctae, (Steinitz 1952); Acanthobrama lissneri (Tortonese, 1952);common name: Lavnun, Sardine or Bleak].

\section{Materials and Methods}

Results given in this paper are the outcome of a long-term study of the distribution and physiology of zooplankton in Lake Kinneret. The experimental methods and sampling program had been documented and published earlier [6,10-12,14-16]. The physiology of Copepoda, Cladocera and Rotifera organisms were experimentally measured in cultures of single individuals in three common Epilimnetic temperatures: $15^{\circ} \mathrm{C}$ in winter, $22^{\circ} \mathrm{C}$ in spring and fall and $27^{\circ} \mathrm{C}$ in summer A brief summarized compilation of previously collected information is re-evaluated here. Consequently, only the data sources and statistical methods are given in this section.

The evaluation of the routinely collected data was done as follows: Weekly sampling results of Nutrients, temperature, phytoplankton, and zooplankton were monthly averaged whilst, Fish Population Size was monitored by Bi-monthly Echo-Survey calculated for the entire lake. For some of the long-term analysis annual means were computed.

\section{Data Sources}

The long-term datasets (1970-2018) of Lake Kinneret and its watershed, including data on the water and air temperature, precipitation, nutrient (mostly forms of $\mathrm{N}, \mathrm{P}$, and $\mathrm{C}$ concentrations) dynamics, lake plankton community structure, lake water level (WL) control (Dam management and pumping rate), and river discharges [15], were statistically evaluated. Data were obtained from the following sources: Kinneret Limnological Laboratory, the Israeli National Meteorological Service, the Israeli National Hydrological Service (National Water Authority). Other data sources were MIGAL, Hula Project Service [3], Mekorot Watar Supply Company Ltd., Monitoring Unit Jordan District, Agriculture Ministry Northern Branch - Upper Galilee Office, and TAHAL Water Planning for Israel (Table 1).

\section{Statistical Methods}

Statistical analyses by fractional polynomial regression, linear regression with $95 \%$ confidence interval indication, simple averages, and line scatter plot were carried out using STATA 9.1. 
Table 1: Parameters.

\begin{tabular}{|c|c|c|c|c|c|c|}
\hline Parameter & Units & Time Span & Sampling Interval & Number of Sampling Stations & Number of Sampling Depths & Number of Points $\mathrm{X10}^{3}$ \\
\hline Temperature & ${ }^{\circ} \mathrm{C}$ & $1970-2018$ & Weekly & 7 & 15 & 260 \\
\hline Nutrients & ppm \& ton/lake & $1970-2018$ & Weekly & 5 & 13 & 12.5 \\
\hline Phytoplankton & $\mathrm{g}(\mathrm{ww}) / \mathrm{m}^{2}$ & $1970-2018$ & Bi-weekly & 1 & 13 & 16 \\
\hline Zooplankton & $\mathrm{g}(\mathrm{ww}) / \mathrm{m}^{2} \& \mathrm{No} / \mathrm{L}$ & $1970-2018$ & Bi-weekly & 4 & 13 & 1.2 \\
\hline Fish Landing & Ton/Year & $1959-2016$ & Annual & Lake & 57 & 67 \\
\hline Fish Population Size & $10^{6} /$ lake & $1987-2016$ & Bi-monthly & 14 Transects & "to: $2 \mathrm{~m}$ " Bottom & 174 \\
\hline
\end{tabular}

The statistical significance of the fractional polynomial test is increasing the flexibility of the conventional polynomial models.

List of Abbreviations in Full:

$\mathrm{BCM}-10^{9} \mathrm{~m}^{3}$

HFCB - Harmful Cyanobacteria;

WL - (lake) Water Level;

FP - Fractional Polynomial Regression;

SPI - Standard Precipitation (rainfall) Index;

RT - Residence Time;

MBSL - Meters Below Sea Level;

WW - Wet Weight;

DW - Dry Weight;

No/L - Number of organisms per Liter;

YOY - Young of the Year (fish);

TC - Total Carbon;

TN - Total Nitrogen;

TP - Total Phosphorus;

$\mathrm{P} / \mathrm{B}$ - Production per Biomass ratio;

$\mathrm{C} / \mathrm{B}$ - Consumption per Biomass ratio;
P/C - Production per Consumption ratio (production efficiency);

PE - Peridinium Era;

ME - Microcystis Era;

TN/TP - Total Nitrogen per Total Phosphorus ratio

PP - Particulate Phosphorus;

SP - Soluble Phosphorus;

PN - Particulate Nitrogen;

$\mathrm{PNz}$ - Nitrogen contained in zooplankton particles

$\mathrm{PPz}$ - Phosphorus contained in zooplankton particles;

\section{Results}

The impact of climate change on the Thermocline deepening as related to the water level (WL) changes and warming are shown in Figures 1-3. The minor changes of zooplankton biomass density (g/ $\mathrm{m}^{3}$ ) in the Epilimnion with respect to the depth of the Thermocline is presented in Figure 4. The Bathymetrical distribution of Zooplankton density indicates high densities at 5-17 $\mathrm{m}$ depth irrespective to the vertical performance of algal Primary Production. The long-term decline of fish landing (Total and Bleak: Mirogrex sp. Acanthobrama $s p$.) whilst fish population size enhancement are clearly indicates in Figures 6 and 7 respectively. The long -term decline (1970-mid-1990`s) and elevation afterwards of zooplankton (Copepoda, Cladocera,

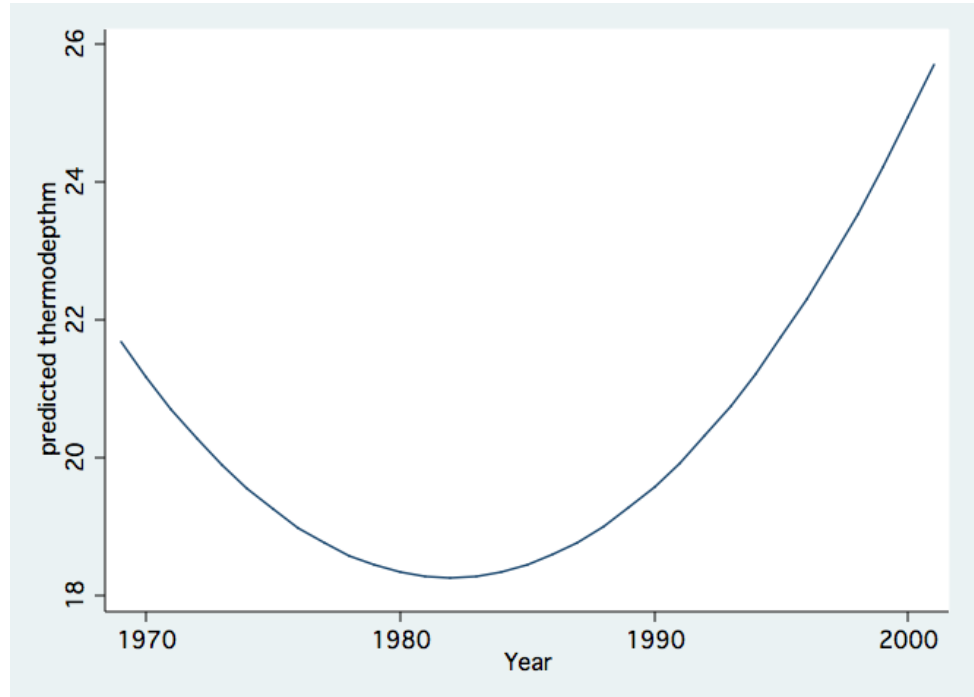

Figure 1: Fractional Polynomial regression between the Thermocline depth and years. 


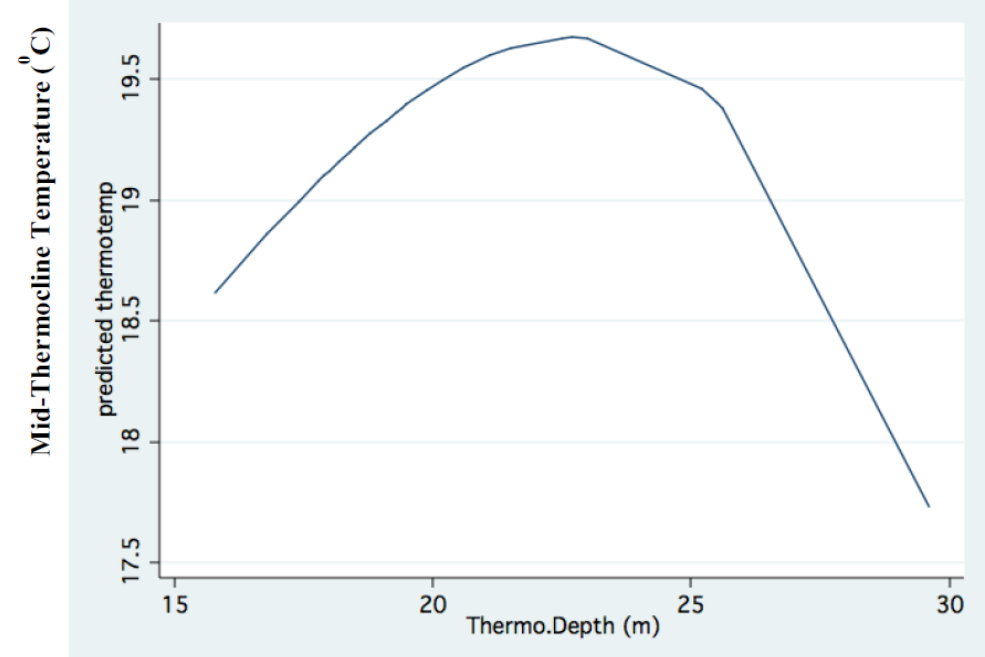

Figure 2: Fractional Polynomial regression between the mid-Thermocline temperature and years.

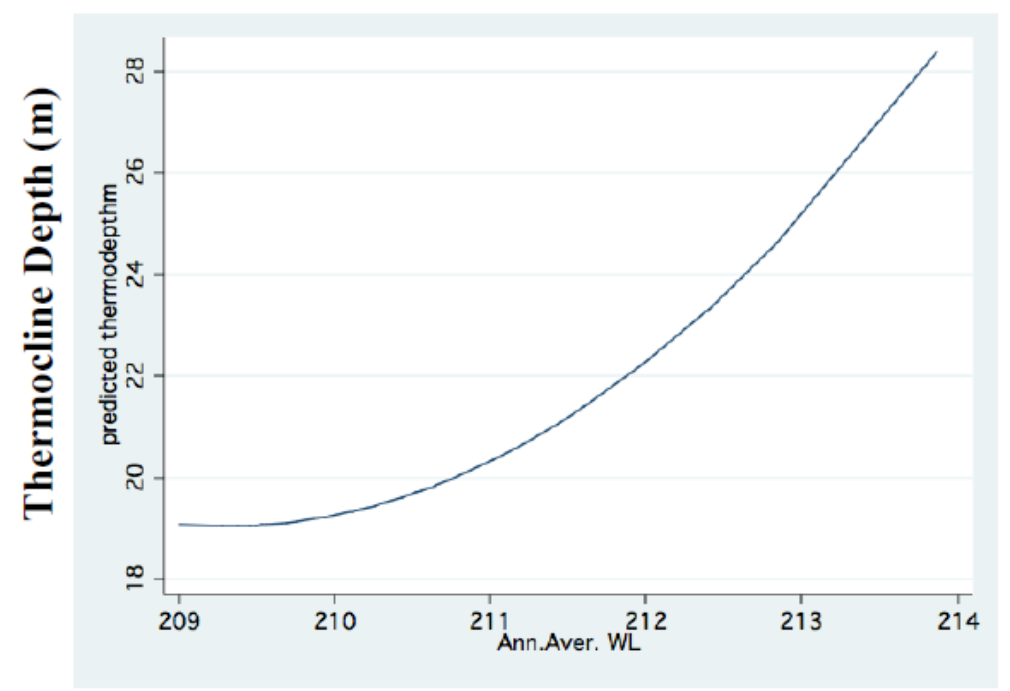

Figure 3: FP regression between Thermocline depth and Water.

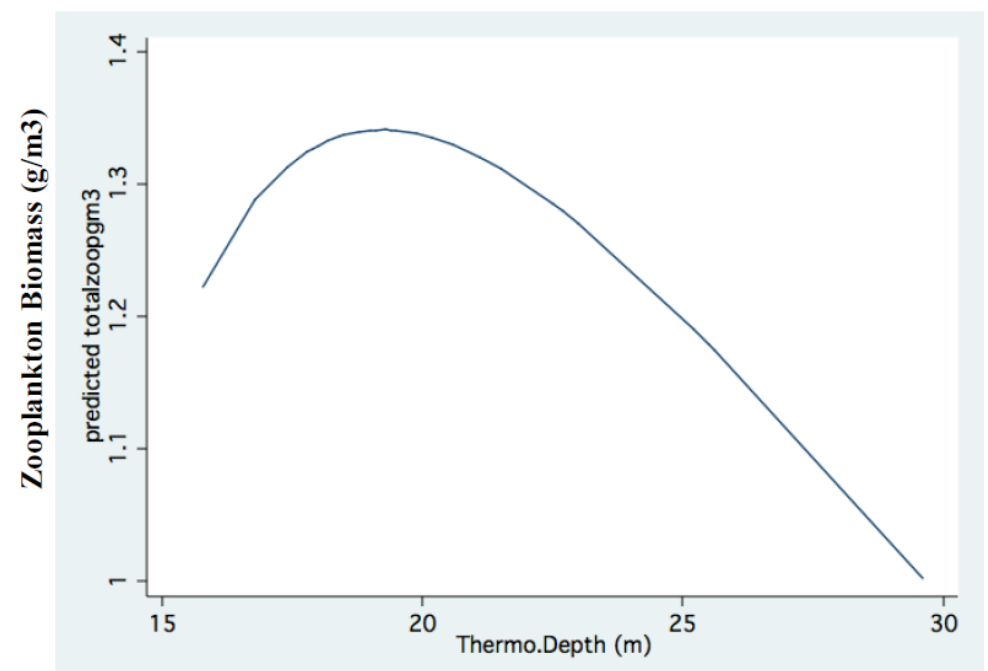

Figure 4: Fractional Polynomial regression between Epilimnetic total biomass of zooplankton concentration $\left(\mathrm{g} / \mathrm{m}^{3}\right)$ and Thermocline depth (m). 


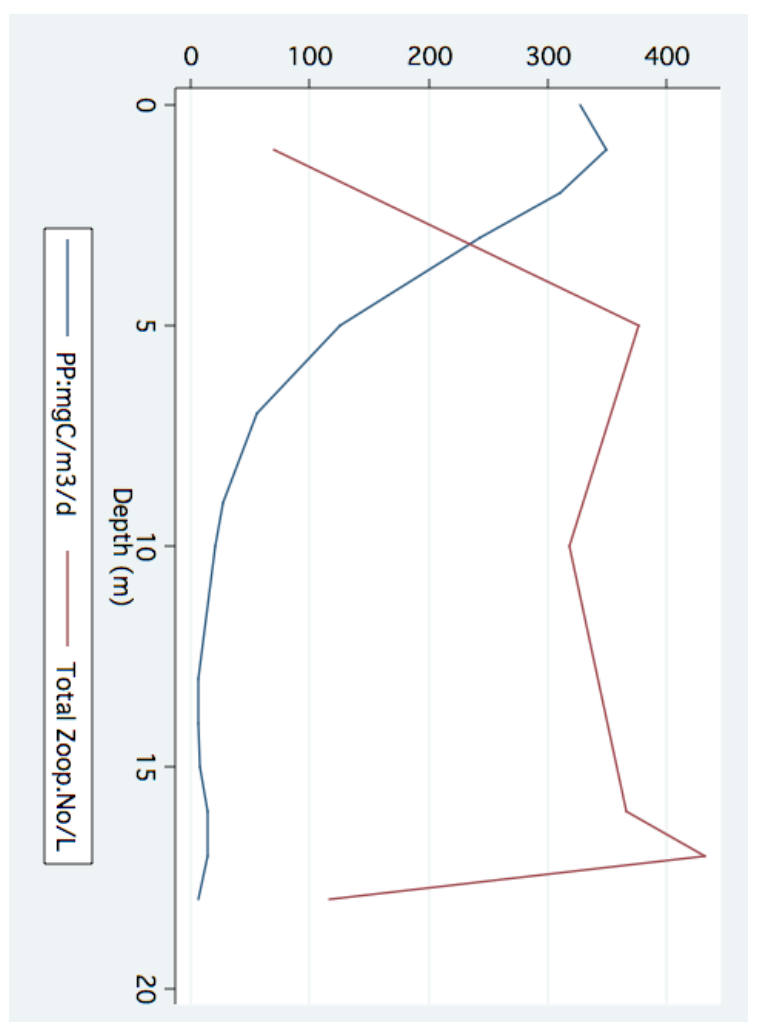

Figure 5: Line scatter of Bathymetric distribution of total zooplankton densities (no/l) and Primary Production ( $\mathrm{mgC} / \mathrm{m}^{3} / \mathrm{day}$ ) (August 1977).
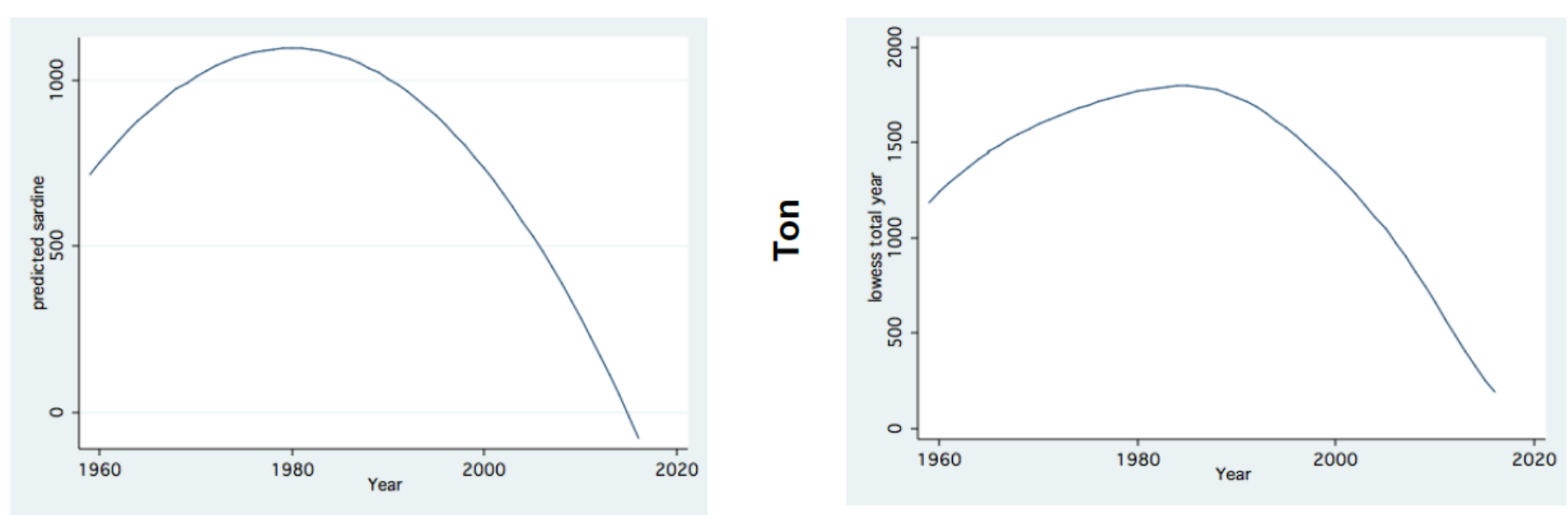

Figure 6: Trend of Changes (LOWESS; 0.8) of Annual Fish landings (ton) in Lake Kinneret (1959-2016); Left: Sardines Right: Total catches.

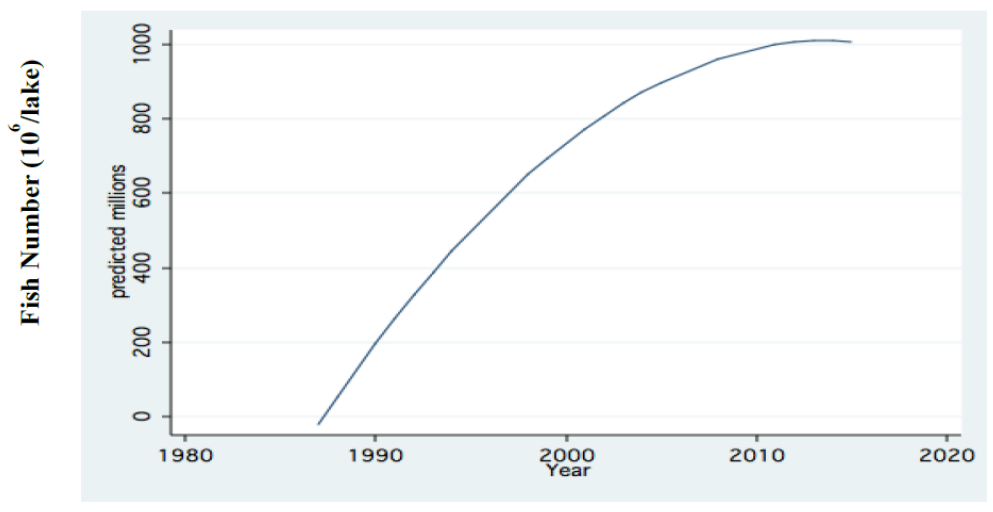

Figure 7: Fractional Polynomial regression between Annual Means of total fish number (10 ${ }^{6}$ ), (all sizes), acoustically recorded in Lake Kinneret during 1987-2016. 
Rotifera) biomass and numerical densities are shown in Figures 8 and 9. The insufficient algal food supply for herbivore zooplankton during 1970-mid 1990's and luxury of availability of edible algal later on is presented in Figure 9. The linear regression between potential prey (Cladocera, Rotifera, Herbivore Copepoda) for predator Copepoda and their density is shown in Figure 10. Figure 10 also indicates long-term increase of the ratio between small and large body size of Cladocera. A significant symptom of climate change followed by precipitation and river discharge decline influenced Total Nitrogen and Total Phosphorus dynamical changes: Total Nitrogen decline and relative slight increase of Total Phosphorus therefore decreased the TN/TP mass ratio (Figures 11 and 12). The consequent modification of algal bloom domination where Cyanobacteria replaced Peridinium are presented in Figures 12 and 14.

The average biomass density of the zooplankton groups (Copepoda, Cladocera, Rotifera) is given in Table 2.

The numerical density of small and large body size of zooplankton and the ratio between them in Lake Kinneret is given in Table 3 as multi-annual (1970-2001) averages; Small size include: nauplii and 1-4 Copepod copepodite stages, 1-3 Cladocera neonates and Rotifera (exclude Asplanchna spp); Large size zooplankton include: 4-5 copepodite stages and adult Copepoda, 3-4 neonates of Cladocera and Asplanchna spp (Table 3).
The physiological parameters that were measured experimentally on individual animals under 3 temperatures were employed for field data of density by species sorting and respective temperature. Monthly and annual and multi-annual means were computed and physiological parameters were calculated (Walline et al 1993). Summary is given in Table 4.

The summary of the study of food source of predator Cyclopoida that was analyzed microscopically is given in Table 5.

The linear statistical regression results between edible algal groups (Chlorophyta, Diatoms) and herbivore zooplankton groups are presented in Table 6.

Experimented temperatures used for the measurements of the zooplankton physiological features were $15^{\circ} \mathrm{C}, 22^{\circ} \mathrm{C}, 27^{\circ} \mathrm{C}$, The zooplankton biomass density $\left(\mathrm{g}(\mathrm{ww}) / \mathrm{m}^{2}\right)$ was calculated as seasonal mean and results are given in Table 7 with respect to presented temperatures.

As part of the long-term changes of nutrient dynamics in Lake Kinneret the analysis of climate change impact on nutrient migration through River Jordan discharge was carried out. The linear regression between organic Nitrogen, Total Nitrogen and Total Phosphorus annual concentration in the River Jordan Water and the discharge was carried out. The results are given in Table 8.

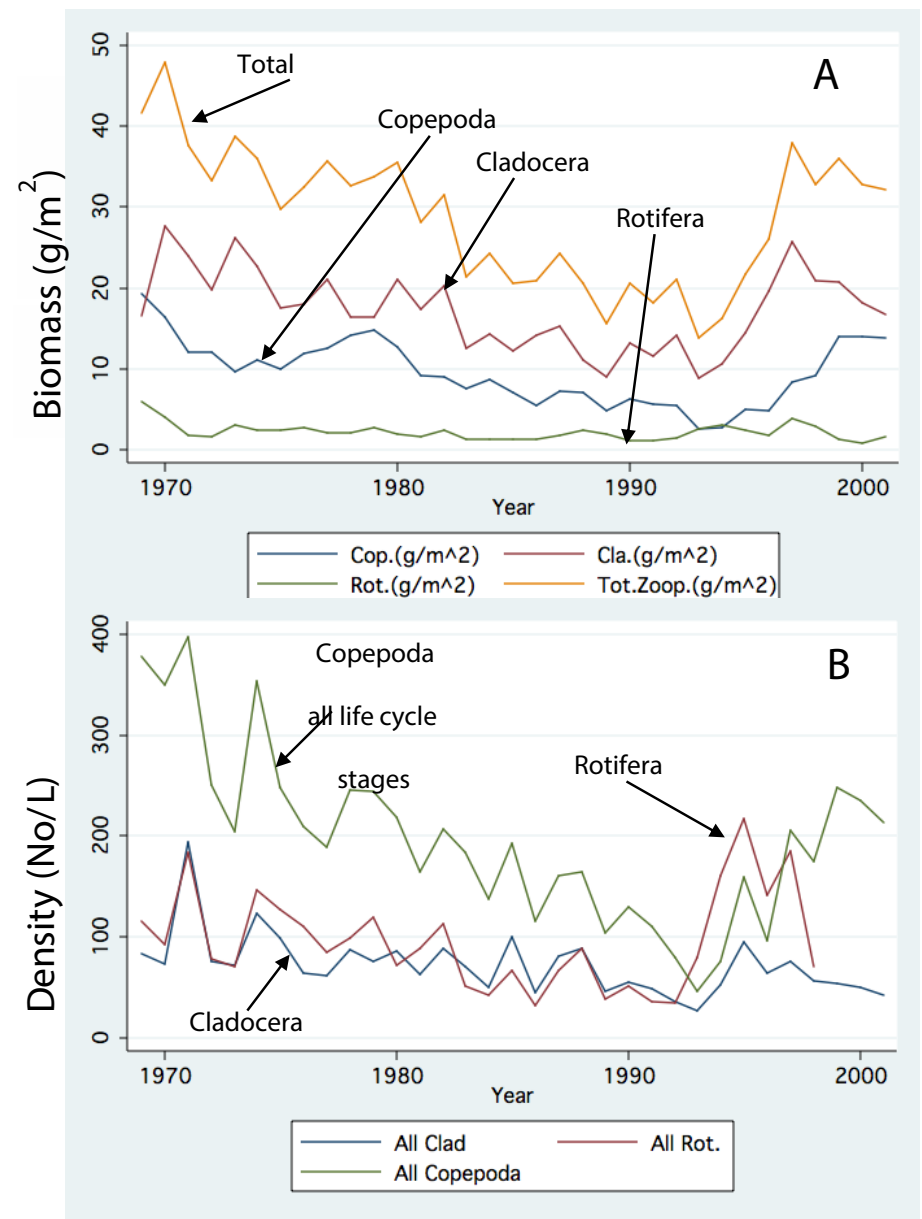

Figure 8: Line Scatter plot of Annual means of monthly averages of Zooplankton densities: Copepoda, Cladocera, Rotifera and total). A - Biomass (g/m²) B - No/l (Copepoda all life cycle stages). 

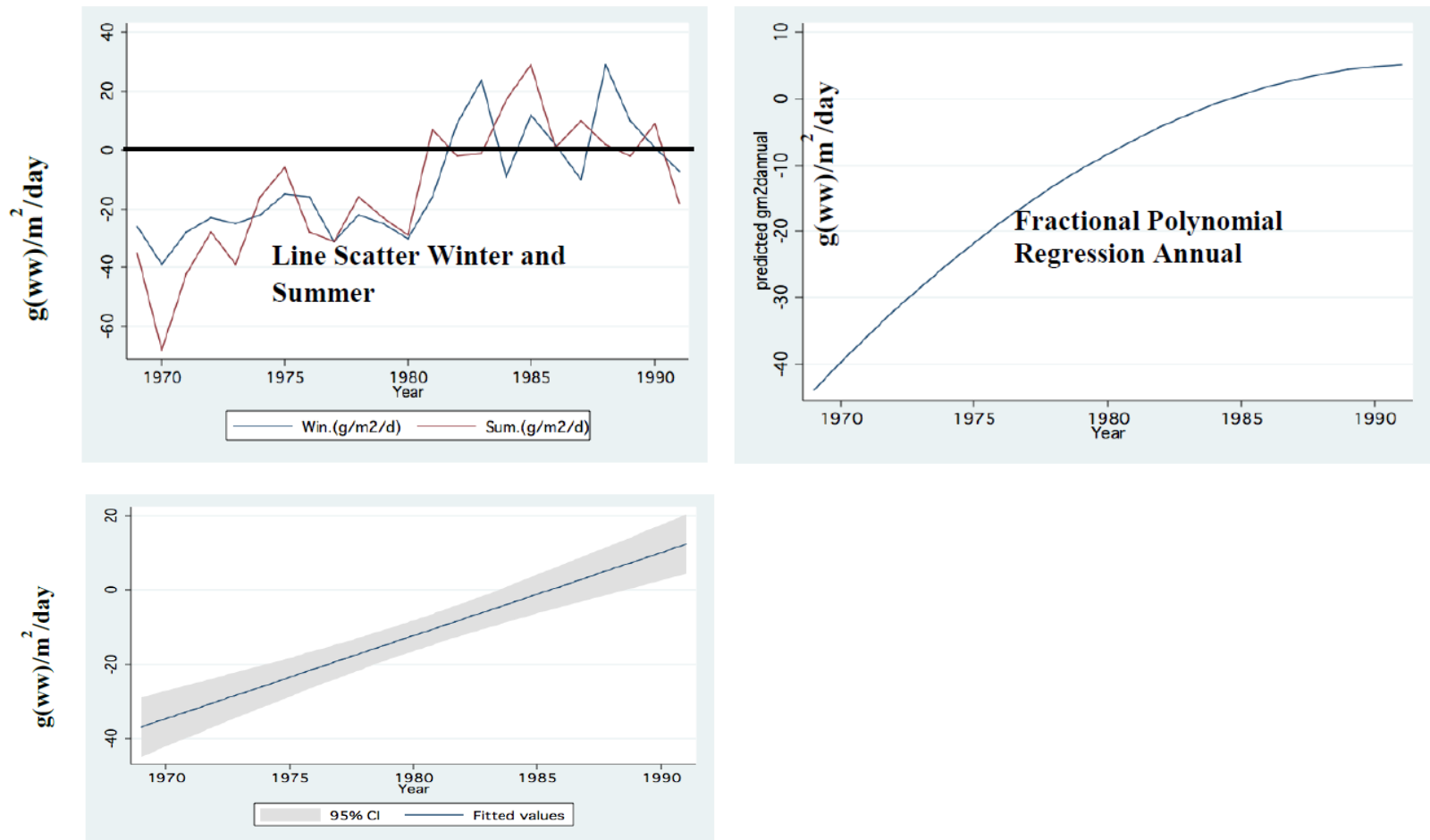

Figure 9: Food Requirement by Zooplankton related to Nano-Phytoplankton availability (g (ww)/m²/day) during Peridinium Era (PE). Zero level mean food is equal to requirement $<$ zero=insufficient food $>$ Zero=Sufficient food (Food exceed requirement)
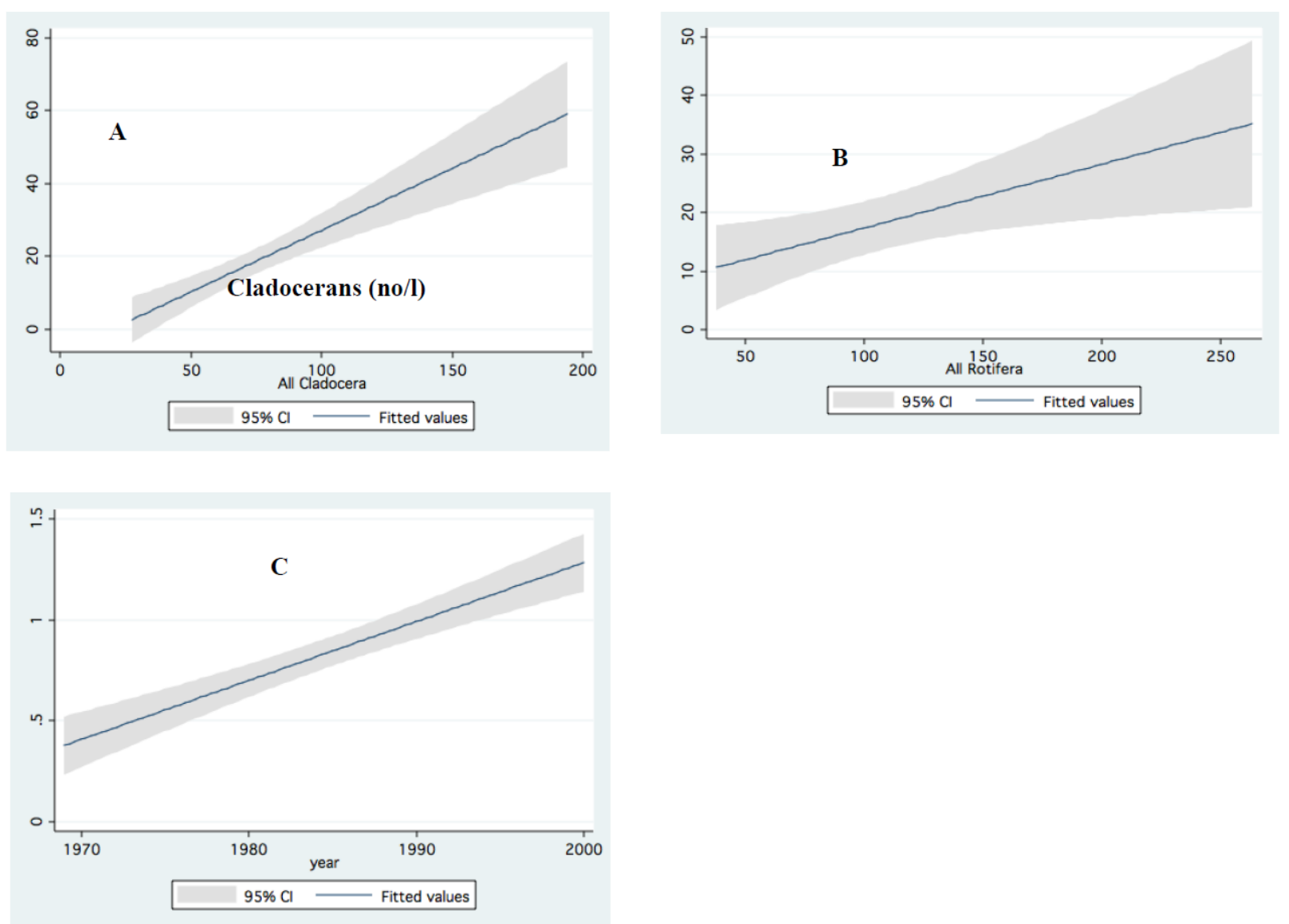

Figure 10: Linear regressions (95\% ci) between: A - Predator cyclopoids and cladoceran; B - Predator cyclopoids and rotifers. C - Large and small cladocerans; Data (No/L) are annual means of monthly averages. 

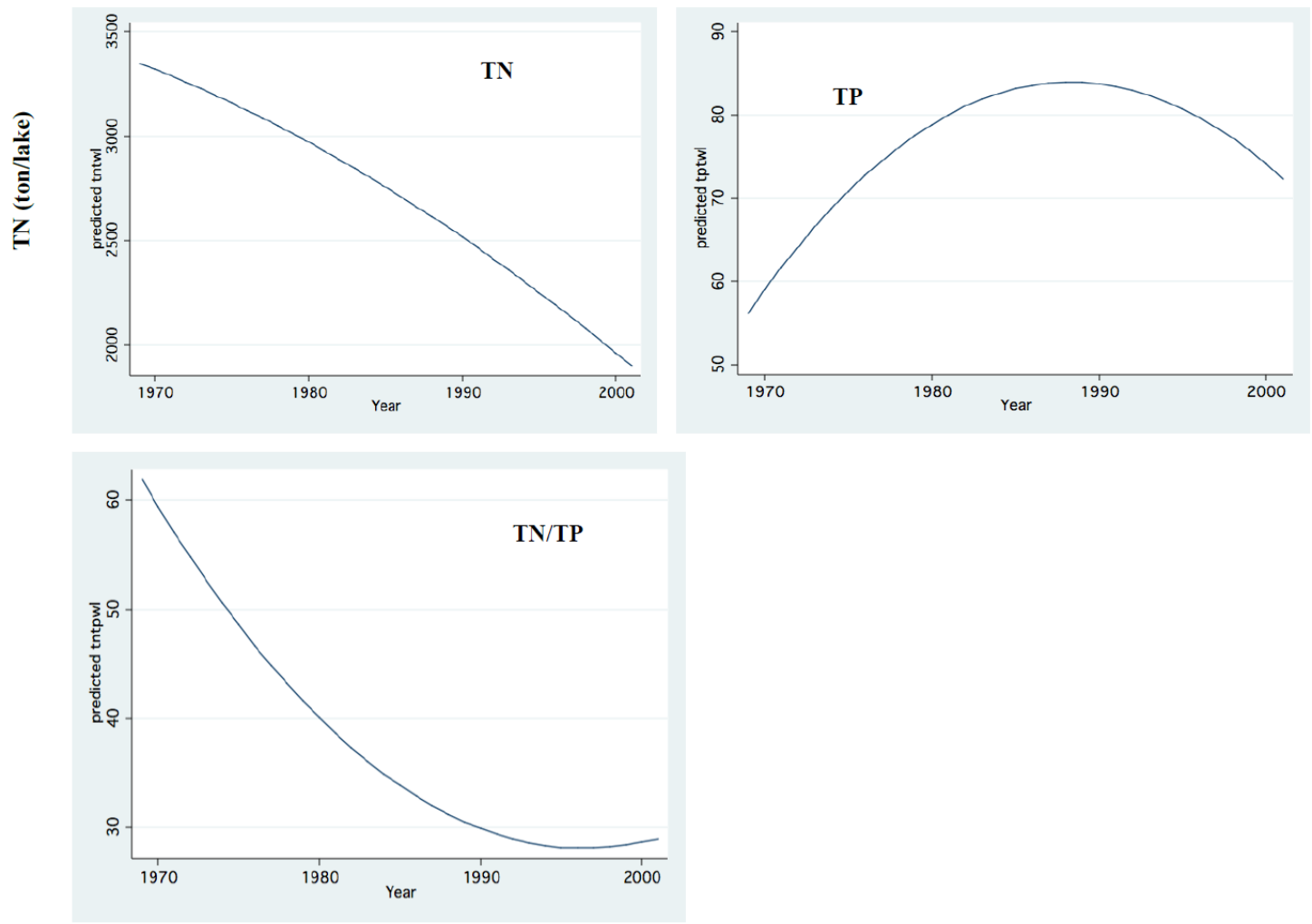

Figure 11: Whole Lake Standing stocks (Ton) of Total Nitrogen (TN), Total Phosphorus (TP) and TN/TP mass Ratio.
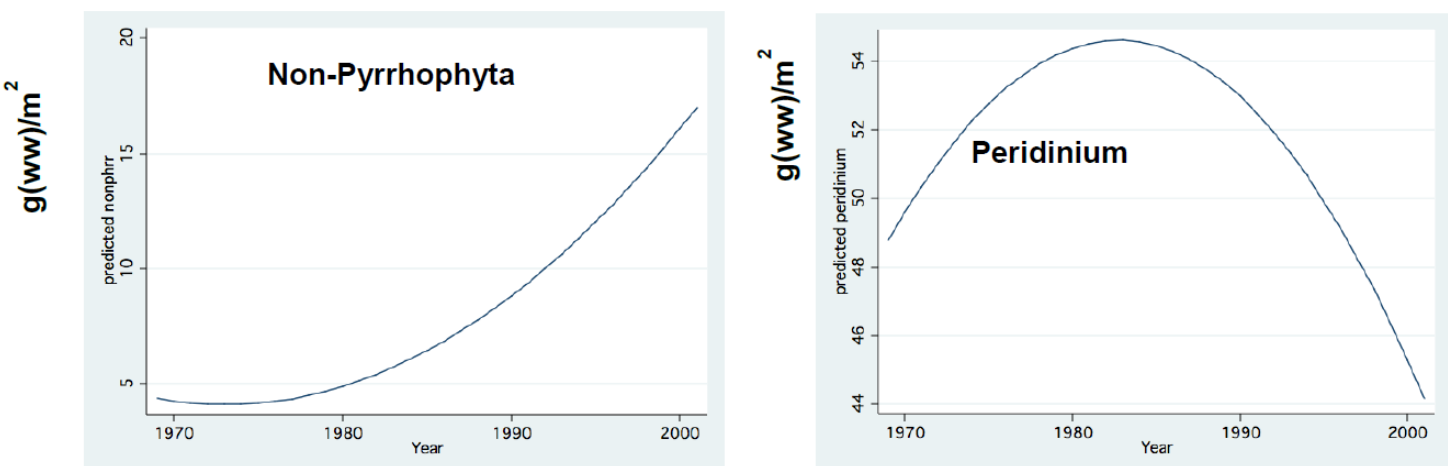

Figure 12: Fractional Polynomial Regression Between: Peridinium and Non-Pyrhophyta monthly means Biomass (g (ww)/m²) and Years; Non-Pyrrhophyte include: Chlorophyta, Diatoms, Cyanobacxteria.

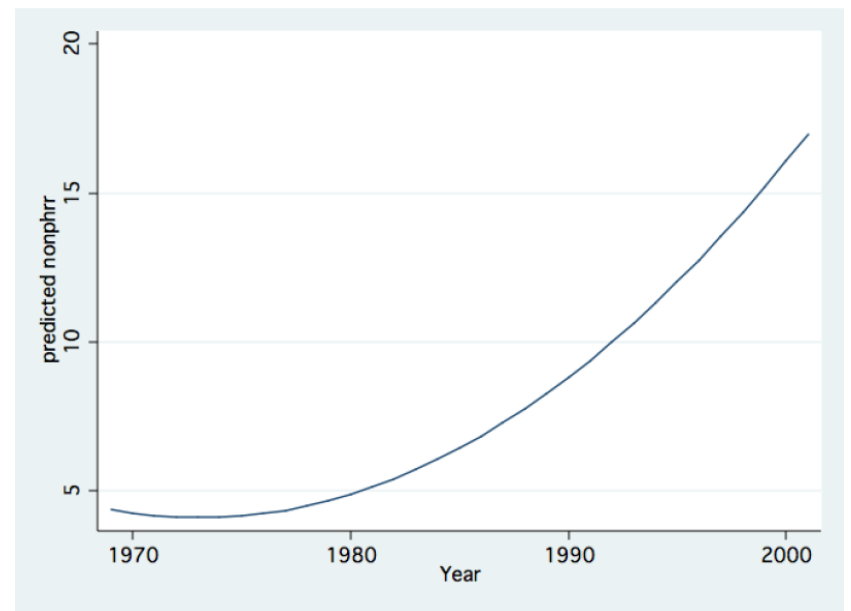

Figure 13: Fractional Polynomial regression between Non-Pyrhophyta Biomass $\left(\mathrm{g} / \mathrm{m}^{2}\right)$ and Years. 

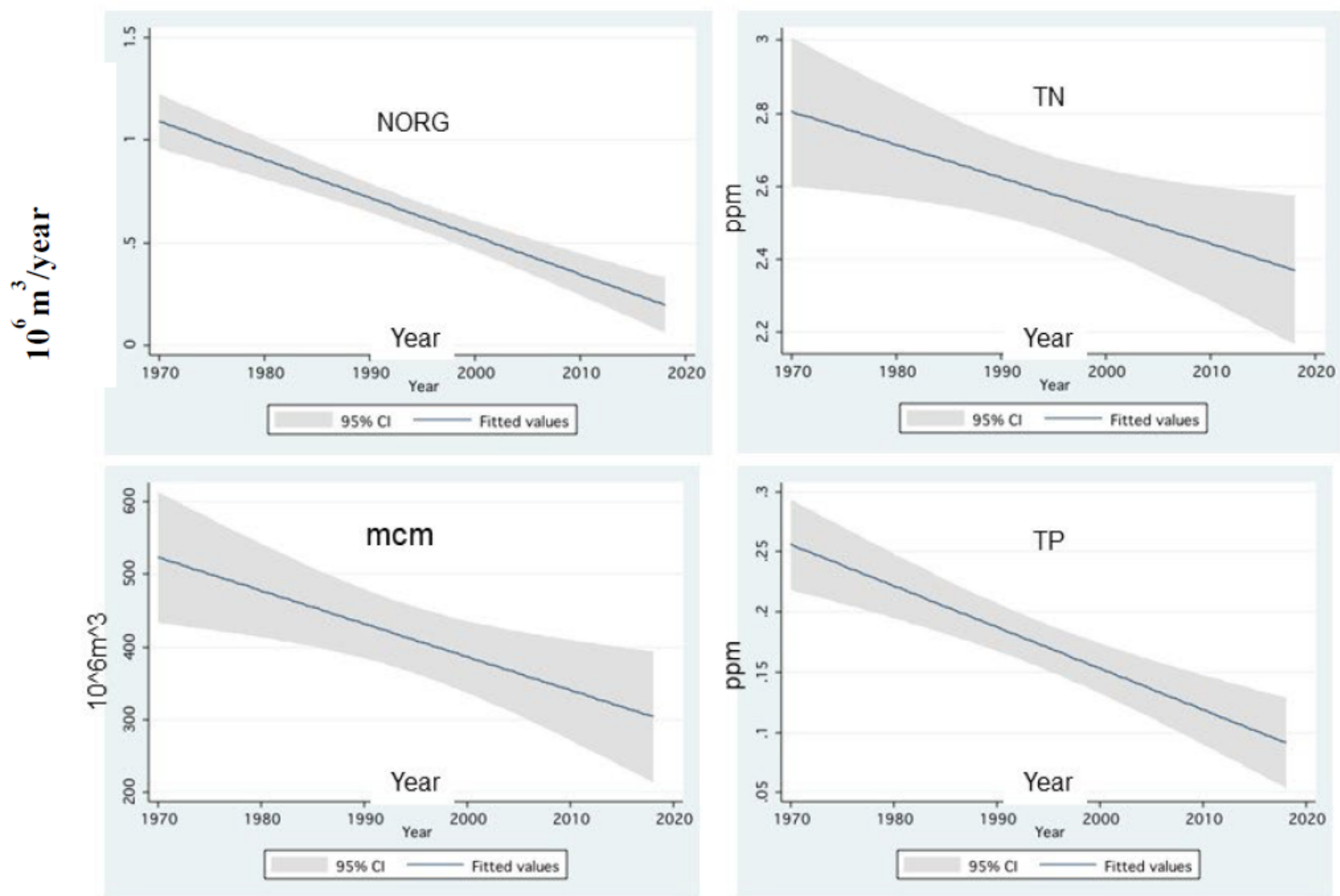

Figure 14: Linear Prediction (w/95\% Ci) between annual averages of Total Nitrogen (TN), Organic Nitrogen (NORG), Total Phosphorus (TP) and annual discharge of River Jordan (mcm, $10^{6}$ $\mathrm{m})$ and Years (1970-2018).

Table 2: Averages of annual (1969-2001) means and Max-Min ranges of zooplankton groups (Copepoda, Cladocera, Rotifera, and Total Zooplankton) WW-biomass $\left(\mathrm{g}(\mathrm{ww}) / \mathrm{m}^{2}\right)$.

\begin{tabular}{|c|c|c|}
\hline Group & Average $\left(\mathbf{g}(\mathbf{w w}) / \mathbf{m}^{2}\right)(\%)$ & Max-Min Range $\left(\mathbf{g}(\mathbf{w w}) / \mathbf{m}^{2}\right)$ \\
\hline Copepoda & $9.0(33)$ & $2.3-17.7$ \\
\hline Cladoceraa & $15.9(59)$ & $8.8-25.1$ \\
\hline Rotifera & $2.1(8)$ & $0.9-5.2$ \\
\hline Total & 27.0 & $12-48$ \\
\hline
\end{tabular}

Table 3: Multiannual averages of annual means of zooplankton group (Copepoda, Cladocera, Rotifera, Total) concentrations (No/L) sorted by body size ( $\mathrm{L}=$ large, $\mathrm{S}=$ small); Ratios of $\mathrm{S} / \mathrm{L}$ are indicated.

\begin{tabular}{|l|c|c|}
\hline Group/Size & No/L & L/S Ratio \\
\hline Copepoda-S & 136 & 0.26 \\
\hline Copepoda- $\mathrm{L}$ & 36 & \\
\hline Cladocera-S & 40 & 0.75 \\
\hline Cladocera-L & 30 & \\
\hline Rotifera-S & 83 & 0.16 \\
\hline Rotifera-L & 13 & \\
\hline Total-S & 259 & 0.36 \\
\hline Total-L & 92 & \\
\hline
\end{tabular}

Table 4: Metabolic parameters of Kinneret Food=Web compartments (Walline et al. 1993).

\begin{tabular}{|l|c|c|c|}
\hline $\begin{array}{l}\text { Food Web } \\
\text { Compartment }\end{array}$ & $\begin{array}{c}\text { P/B: Production/ } \\
\text { Biomass Ratio }\end{array}$ & $\begin{array}{c}\text { C/B: Food- } \\
\text { Consumption/ } \\
\text { Biomass Ratio }\end{array}$ & $\begin{array}{c}\text { P/C: Production/ } \\
\text { Food } \\
\text { consumption }\end{array}$ \\
\hline Bacteria and Protozoa & 360 & 750 & 48 \\
\hline Small Zooplankton & 57 & 280 & 19 \\
\hline Large Zooplankton & 35 & 300 & 12 \\
\hline Zooplanktivore Fishes & 0.9 & 9 & 10 \\
\hline Phytoplanktivore fishes & 1.2 & 10 & 12 \\
\hline
\end{tabular}

Table 5: Number (\%) of Copepoda intensines (freshly collected and immediately analyzed), identifiable food items were indicated and documented.

\begin{tabular}{|l|c|}
\hline Fragments of & Number of predators included prey items (\%) \\
\hline Ceriodaphnia spp. & $170(36.8)$ \\
\hline Diaphanosoma sp. & $110(23.8)$ \\
\hline Cyclopoids & $32(6.9)$ \\
\hline Bosmina spp. & $3(0.6)$ \\
\hline Grey-grained matter & $133(28.7)$ \\
\hline Algae & $15(3.2)$ \\
\hline Total analyzed & 463 \\
\hline
\end{tabular}

Table 6: Statistical parameters $\left(\mathrm{r}^{2}\right.$, all probabilities were $\left.<0.0001\right)$ of multi-annual regression between monthly values of Phytoplankton (Chlorophyta, Diatoms) and Zooplankton (Copepoda, Cladocera, Rotifera) wet biomass (LKDB 1970-2020).

\begin{tabular}{|l|c|}
\hline Plankton Groups & Regression Index $\left(\mathbf{r}^{2}\right)$ \\
\hline Chlorophyta-Vs Copepoda & 0.66 \\
\hline Chlorophyta-Vs Cladocera & 0.55 \\
\hline Chlorophyta Vs Rotifera & 0.27 \\
\hline Diatoms Vs Copepoda & 0.40 \\
\hline Diatoms Vs Cladocera & 0.43 \\
\hline Diatoms Vs Rotifera & 0.44 \\
\hline
\end{tabular}

Table 7: The mean biomass $\left(\mathrm{g}(\mathrm{ww}) / \mathrm{m}^{2}\right)$ of zooplankton groups in three seasons with presented temperatures.

\begin{tabular}{|l|c|c|c|c|}
\hline Season & $\begin{array}{c}\text { Herbivore } \\
\text { opepoda }\end{array}$ & $\begin{array}{c}\text { Predator } \\
\text { Copepoda }\end{array}$ & Cladocera & Rotifera \\
\hline January-April $\left(15^{\circ}\right)$ & 7.4 & 8.6 & 26 & 6 \\
\hline May; November-December $\left(22^{\circ}\right)$ & 5.5 & 6.5 & 24 & 3 \\
\hline June-October $\left(27^{\circ}\right)$ & 6.0 & 7.0 & 22 & 1 \\
\hline
\end{tabular}


Table 8: Linear Regression ( $\mathrm{r}^{2}$ and $\mathrm{p}$ values are given) between Jordan River discharge capacity $(<600 \mathrm{mcm} / \mathrm{y})$ and the concentrations of Organic Nitrogen, Total Nitrogen and Total Phosphorus in Jordan waters.

\begin{tabular}{|l|c|c|}
\hline Nutrient & $\mathbf{r}^{2}$ & Probability (p) (S=significant) \\
\hline Organic Nitrogen & 0.1903 & $0.0039(\mathrm{~S})$ \\
\hline Total Nitrogen & 0.2108 & $0.0022(\mathrm{~S})$ \\
\hline Total Phosphorus & 0.3567 & $<0.0001(\mathrm{~S})$ \\
\hline
\end{tabular}

\section{Metabolic features of Lake Kinneret Zooplankton}

Results from previous field monitoring and experimental studies [6] supplied information about the seasonal and long-term temporary density (no/L) distribution of numerical and biomass density distribution, and zooplankton metabolic (production, respiration, food consumption) activity. The evaluation presented here is an attempt at tentative interlocking of separated chains into a unified ecological web. The following metabolic data were incorporated:

Mean biomass in $\mu \mathrm{g}(\mathrm{ww}) /$ individual [6,11-13]:

Herbivore Copepoda (nauplii, copepodites 1-4 stages) - 3.2; 46\% of total Copepoda;

Predator Copepoda (copepodite 5, adults) - 14; 54\% of total Copepoda;

Cladocera - 21.9; small Rotifera - 1.0;

The conversion of wet biomass to carbon content was based on the following: Dry weight (DW) is $10 \%$ of wet weight (WW) and carbon content is $44 \%$ of DW $[6,8,13]$.

A full-year cycle was divided into three seasons based on commonly monitored Epilimnetic temperatures $[1,6]$ :

January-April: $15-20^{\circ} \mathrm{C}$; May and November-December: $20-24^{\circ} \mathrm{C}$; and June-October: $24-28^{\circ} \mathrm{C}$.

The long-term record of the mean biomass measured in three seasons of the zooplankton groups is given in Table 7.

\section{Discussion}

\section{Climate Change}

\section{Long-term Dynamics of Thermal Structure, and Plankton}

The Israeli climate conditions vary from the desert climate in the south to the subtropical climate in the north (Lake Kinneret and its watershed included) and the wet and mild Mediterranean climate in the center. Rain distribution over Israel (total 7.9 BCM/y) varies between 1300 (north) and less than $100 \mathrm{~mm} / \mathrm{y}$ (southern desert). The total national water supply is $2.11 \mathrm{BCM}$, of which $0.55 \mathrm{BCM}$ comes from the Lake Kinneret-Jordan ecosystem 0.7 BCM are desalinated, and the rest are taken from Aquifers, regional drainage basins and reuse. Consequently, the Lake Kinneret water quality is a national concern, and zooplankton features as part of the energy flow system within the food web are essential.

The climate change in dryness trend was expressed as an increased frequency of negative SPI (standard precipitation index) values, periodic prolongation of the drought season, and irregularities in the rainfall pattern. There was a decline in total rainfall volume, river discharge, and water input, which was accompanied by a decline in the lake WL. The entire symptom of climate change was progressive Dryness expressed as the enhanced frequency of drought seasons initiated an elevation of lake water salinity and consequent reduction in lake water exchange and prolongation of water residence time (RT) from 5 to 18 years [3]. The RT elongation also enhanced change in nutrient dynamics, such as salt accumulation and decline in Epilimnetic nitrogen availability. The lack of Epilimnetic nitrogen caused Peridinium decline [3] but no significant change in potential zooplanktonic food resources. Ecological response to these climate changes in the lake was probably zooplankton eco-physiological behavior, such as enhancement in growth rate, or physical changes, such as modifications in thermal structure [6-8]. Cyanobacteria growth was enhanced by change in nutrient dynamics and increase in temperature. Cyanobacteria are regarded as competitors to other algal groups, such as Pyrrhophyta under the temperature elevation process and the decline of Nitrogen. Temperature increase also affected the zooplankton populations. The impact of temperature on the metabolic trait of zooplankton was documented [6]. Moreover, the sensitivity of the simulated model outputs established that the most sensitive parameters (over the full parameter space) were related to the zooplankton grazing rate, temperature responses, and food limitation [9]. The impact of Cyanobacterial bloom formation on water quality includes toxin production, which negatively affects vertebrate and invertebrate organisms. All these ecosystem changes are recognized as symptoms of the Eutrophication trend.

The reduction in water inputs caused a decline in the lake's nitrogen supply, creating Epilimnetic insufficiency of nitrogen, which caused the disappearance of the long-term (1960-1995) documented Peridinium bloom formation. The Peridinium bloom was replaced, among other genera of Cyanobacteria, by HFCB (toxic), $\mathrm{N}_{2}$ fixers, and non- $\mathrm{N}_{2}$ fixers.

A significant result of climate change was changes in the depth and the temperature of the Thermocline. Figures 1-3 indicate the following: since early 1980s, the Thermocline has deepened by app. 8 meters (Figure 1); Thermocline deepening from $22 \mathrm{~m}$ to $28 \mathrm{~m}$ was accompanied by a temperature drop of about $2^{\circ} \mathrm{C}$ (Figure 2). Moreover, the decline in lake water level (WL) from 210 to $214 \mathrm{mbsl}$ was accompanied by Thermocline deepening by app. $8 \mathrm{~m}$ (Figure 3). These climate change conditions were comparatively tested against zooplankton density (Figure 4) [10]. The monthly means of biomass concentrations in $\mathrm{g}(\mathrm{ww}) / \mathrm{m}^{3}$ (volumetric) were converted to densities per $\mathrm{m}^{2}$ (aerial). A multi-annual (1970-2001) total average summary of the vertical distribution of zooplankton as related to the Thermocline deepening, in terms of $\mathrm{g} / \mathrm{m}^{3}$ and $\mathrm{g} / \mathrm{m}^{2}$, indicated minor changes: 1.35 $1.05 \mathrm{~g}(\mathrm{ww}) / \mathrm{m}^{3}$ and $27-30 \mathrm{~g} / \mathrm{m}^{2}$. Nevertheless, seasonal as well as diurnal fluctuations were significant. Several studies documented the diurnal vertical migration of zooplankton. High concentration of zooplankton at the upper part of the Thermocline during the stratification period was documented (Figure 5). Bruce et al. [7] concluded that the relative contribution of zooplankton to the Epilimnetic inorganic stock of nutrients varied seasonally in response to the thermal cycling of stratification/mixing periods. Moreover, zooplankton Epilimnetic excretions were highest (62\%) during summer stratification and lowest (2\%) during the winter turnover periods [6]. 


\section{The Role of Zooplankton in the Lake Kinneret Ecological Services: Fishery}

The zooplankton research was focused on the pelagic zone. The Lake Kinneret littoral volume is estimated to be less than $10 \%$ of the Epilimnion volume. Nevertheless, the littoral function as a fish nursery space is significant. The eco-physiological trait of zooplankton discussed here is due to the pelagic zone. A similar consideration is also attributed to the benthic fauna, which is active in recycling sediments but less involved in the eco-physiological activity within the water column.

The ecological involvement of zooplankton within the Lake Kinneret service objectives obviously has to do with the interrelationship with fish. Nevertheless, the Lake Kinneret ecological services are much wider as multi-targets: water supply, aquatic recreation, tourism, nature protection and commercial fishery. The aquatic recreation service is correlated with the protection of fish reproduction grounds (spawning, display, and young of the year (YOY) fish training), and zooplankton availability was partly damaged by both WL decline, beach vegetation dispersal and littoral suitability, as well as water quality deterioration. The availability of zooplankton prey density for the new born fingerlings is significant for the renewal of the pelagic fish community by the young generation emerging from the littoral zone. Consequently, the impact of the Cyanobacterial bloom dominance has an economic implication for the utilization of Lake Kinneret.

The zooplankton body size included in this study fell between 0.1 $2.0 \mathrm{~mm}$. Although most of the free-swimming freshwater zooplankton organisms belong to the small-size invertebrate taxa of Cladocera, Copepoda and Rotifera, there are more, including (among others) Ciliata, Flagellata, Turbelaria, Nemertea, Gastrotricha, Nematoda, Nematomorpha, Ostracoda, Isopoda, Amphipoda, and Hydracarina. Zooplankton research in Lake Kinneret always aimed at ecological aspects which are critical for good water quality. Therefore, this paper is focused on the dominant pelagic organisms.

\section{Zooplankton Densities}

The term (1969-2001) averages of zooplankton biomass (WW) density in Lake Kinneret are given in Table 2 as averages and ranges (max-min) of annual means.

Zooplankton concentration (No/L) density, expressed as the number of individuals per liter sorted by body size (small and large classes), is given in Table 3.

Results in Tables 2 and 3 indicate that the majority of zooplankton biomass are adult Copepods and Cladocerans, although young Copepoda stages (nauplii) and Rotifers are most numerous.

The body size ratio (large/small) of the zooplankters indicates the dominance of visual particulate fish feeding habits maintained by YOY of Bleaks and Tilapias. The larger organisms are more visible and therefore more vulnerable to predators. The higher number of young instars than adults throughout the life cycle is common in nature and ensures the sustainability of the organism. The impact of intensified visual-attack predation pressure by Bleak fishes on large-bodied adults enhances this situation: adult (large body size) elimination boosts the number of young instars, making them more abundant. It has been observed that the fingerlings of most of the Lake Kinneret fish species populating the shallows are filter feeders that do not discriminate prey by size. The information given in Tables 2 and 3 considers the pelagic zone populations, where bleaks are the majority.

The impact of the body size of zooplankters on the functional trait of the whole community is significant (Table 3). Biomass measure is affected by body size and large organisms contribute more than small ones. Nevertheless, specific activities like food consumption, excretion, respiration, reproduction, mortality, and population turnover time of small organisms are higher than those of large organisms. It is noticeable that such a comparative attitude is limited to different body sizes of adult or offspring stages of the same species. The most common Copepod in Lake Kinneret, Mesocyclops oggunus, maintains 10 life cycle stages that are dissimilar in morphology, size and physiological trait, including nauplius, copepodite instars and adult. Moreover, the differences in instars also include differences in swimming behavior and vulnerability to predators.

\section{Total Load of Zooplankton Biomass}

The evaluation of the role of zooplankton in the Lake Kinneret ecosystem is based on their body mass and nutrient content (Table 4). The zooplankton wet biomass (WW) in the Epilimnion of Lake Kinneret varies between 15 and $50 \mathrm{~g}(\mathrm{ww}) / \mathrm{m}^{2}$, which is $2520-8400$ tons in the whole lake (lake surface area at maximal WL is $168 \mathrm{~km}^{2}$ ). If the dry weight (DW) of zooplankton is $10-20 \%$ of the WW $[2,6,8]$ the DW biomass of the zooplankton compartment range in Lake Kinneret is 250-1700 tons. Taking into account the published data [17-20] on Carbon $(\mathrm{C})$, Nitrogen $(\mathrm{N})$ and Phosphorus $(\mathrm{P})$, their content ranges (48\%, 9\%, 1\% of DW respectively) in the Lake Kinneret zooplankton are 120-860 tons, 23-153 tons and 2.5-17.0 tons respectively. These nutrient loads are small in relation to the total stocks, but they might have a significant role due to the high rate of nutrient recycling by zooplankton. Moreover, acoustic surveys carried out in Lake Kinneret (Table 1) have indicated a total fish stock (WW) similar to zooplankton standing wet stock biomass, but recycling and food consumption are significantly dissimilar (Table 4). Daily food consumption by fish makes up about $5-20 \%$ of fish body wet weight, whilst daily food consumption by zooplankton constitutes about $80-110 \%$ of its body wet weight [6].

Daily fish consumption is about $5-20 \%$ of their body wet weight whilst zooplankton $-80-110 \%$ [8], the reproduction rate (population turnover time) of fishes is scaled annually whilst that of zooplankton is measured in week-months measure. The role of Bacteria, Protozoa, Zooplankton and fish food web compartments are presented in Table 4.

The min-max ranges of lake nutrient (TC, TN, TP) stocks (ton), as commonly documented in Lake Kinneret during the winter mixing period, are as follows:

\section{TC: $16564-26476$ ton}

TN: 2032-4092 ton

TP: 44-128 ton 
The TC, TP, and TN content ranges (max. during winter-spring bloom - min. when no bloom in summer) (ton/lake) within the food web compartments are given below [11]:

Zooplankton: $302 \mathrm{t}$

Fish: $1478 \mathrm{t}$

Phytoplankton (max-min): 4536-504 t

Particulate organic carbon (max-min range): 14280-20160 t

Dissolved organic carbon (maximum bloom level): $17136 \mathrm{t}$

Detritus and dissolved forms were responsible for the majority (76$86 \%$ ) of the Carbon content, whilst living organisms (zooplankton, fish, phytoplankton) contain a minor part of the standing stock of Carbon in the Lake Kinneret ecosystem. The standing stock ranges (max-min) of TC, TN and TP in Lake Kinneret are 16564-26476, 2032-4092, and 44-128 ton, respectively. Based on data shown previously, the $\mathrm{P}$ and $\mathrm{N}$ content percentage in the Lake Kinneret fish and zooplankton is lower than $1 \%$, and in phytoplankton is $3-17 \%$. In other components, the $\mathrm{P}$ and $\mathrm{N}$ content is due to particulate and dissolved organic matter. When a similar evaluation was carried out for bacteria and protozoa, the results indicated even lower measures. The role of the food web compartment in the energy flow pattern through the ecosystem material cycling and turnover time was documented by Serruya et al. [8] and Walline et al. [9], and later modeled by Bruce et al. [9] and Gal et al. [10]. The turnover time of phytoplankters is measured in days, of Bacteria and Protozoa in hours, of Zooplankton in weeks, and of fish in years. Conclusively, the impact of zooplankton is probably higher than that of fish and lower than that of phytoplankton, Bacteria and Protozoa. Bruce et al. [7] indicated that about $51 \%$ of photosynthetic Carbon is consumed by zooplankton and the excretion of dissolved nutrients by zooplankton accounts for $3-45 \%$ and $5-58 \%$ of $\mathrm{P}$ and $\mathrm{N}$ uptake by phytoplankton, respectively. The following parameters represent the metabolic trait of the Lake Kinneret food web compartment: $\mathrm{P} / \mathrm{B}$ - the ratio of production to biomass; $\mathrm{C} / \mathrm{B}$ - the ratio of food consumption to biomass; $\mathrm{P} / \mathrm{C}$ - the percentage of production efficiency, which is the ratio of production to food consumption. These metabolic parameters were calculated for Phytoplankton, Bacteria and Protozoa, small Zooplankton (herbivores), large Zooplankton (predators), known zooplanktivore fishes (Bleaks), and in general planktivore fishes (Tilapia); the results are given in Table 4 [11].

Information given in Table 4 indicates very high production and nutrient consumption by bacteria and Protozoa. Therefore, it is suggests that most of their production is utilized by consumers at a higher food web level. Zooplankton is preyed upon by fish (all zooplankton stages are consumed by fish) and a minor part by invertebrate predator (adult Cyclopoid). It should be noted that the zooplanktivore fishes (Bleaks) are dominant ( $>90 \%$ by biomass and number) in the Lake Kinneret fish community. This may be an indication why about $80 \%$ of the zooplankton biomass is transferred to a higher food web level [12,13] (Figure 10).

\section{Fish-Zooplankton Community Interrelationships}

Two major changes were documented within the Lake Kinneret fishery and consequently in fish communities: A) The fishery of
Bleaks diminished close to a zero level due to the loss of market demands initiated by the absence of motivation for fishing them (Figure 6). As a result, Bleak stock size increased significantly (Figure 7). The proliferation of Bleaks undoubtedly intensified zooplankton suppression. B) Tilapia (mostly S. galilaeus) fishery crashed from the normal landing of 250-350 tons to less than 10 tons of annual fishery. Nevertheless, this decline in Tilapia fishery was naturally rehabilitated, but due to Peridinium elimination, Tilapia slightly shifted to prey on zooplankton for part of their diet. The outcome given in Figures 6-9 is a classical event of complex interactions in lake communities. Bleak fishery diminished as a result of reduction in market demand, leading to an increase in Bleak population (Figures 6 and 7) and, consequently, intensifying the pressure on zooplankton population, which caused a decline in the zooplankton density (Figure 8). The elevation of zooplankton stock biomass from the mid-1990s was due to the implementation of the subsidized Bleak fishery program. Between 1995 and 2002, more than 5000 tons of unwanted largeand small-sized Bleak fishes were removed, partly to garbage dump and partly marketed. The change in the Phytoplankton community structure (Peridinium replacement by Cyanobacteria) enhanced the predation of zooplankton by Bleaks and Tilapias. The ecological events within the lower level of the trophic pyramid (zooplankton-nanophytoplankton) are shown in Figure 9. The total food requirement was calculated [8] and balanced with the available nano-phytoplankton stock biomass. These relations were evaluated by two regression methods between food requirement and years (Figure 9): Fractional polynomial regression (annual means of $\mathrm{g} / \mathrm{m}^{2} / \mathrm{d}$ ) and linear regression ( $95 \%$ confidence Interval); the line scatter is shown in Figure 9. Results in Figure 9 indicate that before 1985, when Peridinium was dominant, food algal resources were insufficient to meet zooplankton demands and other sources (detritus, Protozoa, Bacteria) were probably utilized, but later on (1985-1990) algal sources became sufficient. It is suggested that algal food sufficiency resulted from both the decline in zooplankton stock biomass and slight enrichment in phosphorus in the Epilimnetic resources (Figure 11).

\section{The Role of Invertebrate Predation}

The absence of significant predator invertebrates in Lake Kinneret has been previously confirmed [8]. The only known carnivorous zooplankter is the adult stages of cyclopoid copepods (Mesocyclops oggunus), which are commonly present as a mixed-age copepod population throughout a full-year cycle. Earlier studies documented the predatory habits of the adult copepods [11-13]. A combination of gut content analysis and experimental study has yielded results that confirmed the predation of Ceriodaphnia spp. and Diaphanosoma sp. and cannibalism; however, the very common Bosmina spp were not preyed upon. The results of gut content analysis of large-body Copepoda (copepodite $4 \& 5$ and adult males and females) [11] are given in Table 5.

Results in Table 5 represent a combined investigation of feeding trials of live organisms and microscopic observations of animal feeding behavior. The limited impact of invertebrate predation on zooplankton density was confirmed. Nevertheless, Gal et al. [10] presented a data-driven model of zooplankton dynamics and indicated that the abundance of predatory Copepoda determines the population size of 
herbivores and micro-zooplankton rather than their food sources. In other words, the top-down cascading effect is dominant. That is, predator Copepoda control the population size of herbivore Cladocera and rotifers. Copepoda gut content, as studied by direct microscopic observations and experimental research, confirmed the dominant topdown effect achieved mostly by zooplanktivore fish. That is a scientific disputed meeting between modeling and solid observed results. The impact of vulnerability was also indicated, where the fast swimmer, Diaphanosoma, was preyed upon by Bleaks less than slower than Diaphanosoma-moving Ceriodaphnia. Moreover, no preyed items (trophy, lorica plates etc.) of Rotifera and residuals of Bosmina spp. were found in the cyclopoid gut contents. On the contrary, food resources for Bleak and young fish stages (YOY, fingerlings) of most of the Lake Kinneret fish species were confirmed (by gut content analysis and experimental studies) as many zooplankton species. The conclusion by Gal et al. [10] about intraguild predation of zooplankton by both fish and invertebrates is incomplete, as confirmed by experimental study and microscopic observations. The Lake Kinneret food web includes both visual-attacker fish predators, which prefer large-body invertebrates and slow swimmers (zooplankters), and filter-feeder fish, which ingest zooplankton of all sizes. It is therefore concluded that the impact of zooplankton predation on the entire invertebrate community is minor and free-swimming small animals are preyed upon mostly by fish (cascading top-down eco-force) (Figure 10).

\section{Zooplankton-Phytoplankton Interactions}

The long-term record of the River Jordan-Lake Kinneret ecosystem indicates, a reduction in Total Nitrogen and a slight increase in Total Phosphorus input and in the Lake Kinneret Epilimnion (Figure 11). These changes also induced a decline in the TN/TP mass ratio, in the Lake Kinneret Epilimnioin which was favored by Cyanobacteria. Rachamim et al. [14] suggested the influence of WL decline on the nutrient content in particulate matters. The decline in headwater discharges, followed by the decline in the lake WL, enhanced the prolongation of residence time (RT) followed by Nitrogen input decline, accompanied by outsourced Phosphorus (dust deposition, bottom sediments) slight increase. As a result of temperature elevation and Nitrogen deficiency, there was significant reduction in the biomass of Peridinium spp, which was replaced by non-phyrrhophyte species, mostly Cyanobacteria but also Chlorophyta and Diatoms (Figures 13 and 14). It is suggested that the changes in the phytoplankton community structure are due to regional climate changes. A long-term record of the Lake Kinneret phytoplankton [1,2] revealed significant modification in the algal community since the 1990s. Consequently, the phytoplankton-zooplankton interaction is include two periodic eras: the "Peridinium Era" (PE) before the 1990s and the "Microcystis Era" (ME) afterwards. Results given in Tables 4 and 7 are accounted for by PE conditions. The biomass density of nonphyrrhophytes in summer months was significantly elevated during the PE: Statistical regressions of monthly (May, June, July) density vs. Time (month) resulted in the following ranges: $\mathrm{p}=0.02-0.03$ and $r^{2}=0.46-0.52$, indicating significant summer increase. Although available food biomass was significantly elevated, it was insufficient due to the summer temperature elevation which enhanced the zooplankton demand. These are the common summer conditions which represents the "Lake Kinneret Summer Paradox of Steady State" (Figures 9 and 13) [8]. The geographical climate zone of the Lake Kinneret drainage basin region is defined as subtropical, and therefore the summer season is dry, long and hot, causing a lack of nutrients when the food requirements of all food web compartments are maximal. Nutrients required by algae are accompanied by a high level of animal metabolism, resulting in insufficient supply of energy. The food requirements of the primary (zooplankton) and secondary (fish) consumers are maximal but resources are minimal, leading to insufficient food supply to herbivore and predator zooplankton and fish compartments. Zooplankton predation by fish is enhanced by the mobilization (swimming) capabilities of fish, following downwards the zooplankton migrating towards the top of the thermocline. On the other hand, the diurnal vertical migration of zooplankters enables them to locate, as refuge, darker depths at the top of the thermocline, or upper Epilimnetic layer at night, as well as particle-enriched layers for feeding.

The relative abundance of algal cells in the digestive tracts of Cladocerana (Bosmina spp, Ceriodaphnia spp, Diaphanosoma $s p$ ) was seasonally monitored [11-13], and the results indicated a nano-phytoplanktonic preference. Scenedesmus spp, Tetraedron $s p$, Cosmarium sp, Chodatella sp, Oocystis sp, Pediastrum spp, and Coelastrum $s p$ were the most common algal species in the Crustaceans gut content.

The ratios of monthly changes of edible phytoplankton (Chlorophyta, diatoms) biomass to monthly biomass changes of zooplankton (Copepoda, Cladocera, Rotifera) during the PE represent a relative increase in phytoplankton densities (Table 6). Considering the indirect relation between algal food resources and zooplanktivore fishes, the results in Table 6 indicate the following: long-term zooplankton biomass suppression by fish alleviated feeding pressure on phytoplankton resulting in algal biomass enhancement. It is therefore suggested that the zooplankton suppression was due to fish predation (Bleaks) and nano-phytoplankton was probably affected by an additional factor such as nutrient (most probable Phosphorus) availability. Combined data given in Tables 4 and 6, accompanied by field data from the PE, indicate that there was insufficient algal food for zooplankton in the earlier part of the PE and excess food availability afterwards. Insufficient algal food availability in the early PE and, later, excess algal food availability to zooplankton in summer and winter seasons are shown in Figure 9. Consumption of other food sources, such as Bacteria, Protozoa and detritus, was likely enhanced earlier, but reduced later, in the PE. Considering that zooplankton function as a preventive agent against water quality deterioration within a complex interaction, zooplankton mortality was enhanced by bleak fishes, grazing pressure on nano-phytoplankton was reduced, algal growth was enhanced, and food availability was improved. Furthermore, non-algal food resources for zooplankton probably flourished: PicoPhytoplankton, Bacteria, Protozoa, and detrital particles resulted in the disintegration of the heavy biomass of Peridinium bloom and consequently fish feces. High Nano-Phytoplankton, Bacterial, Protozoa and detrital densities are widely considered as symptoms of eutrophication, i.e.water quality deterioration. 


\section{Zooplankton-Nutrient Relationships}

The impact of zooplankton on the distribution of nutrients $(\mathrm{N}$, P) within the Lake Kinneret ecosystem during the PE was mostly controlled by the following parameters: zooplankton homeostasis (stoichiometry), algal food resource growth rate and consequent availability, geochemical properties of the Lake Kinneret waters, and thermal structure (stratification stability). It has been documented $[8,15]$ that $71 \%$ and $29 \%$ of the Lake Kinneret nitrogen stock in the water column exist as suspended particles (plankton and detritus) and as dissolved forms, respectively. About $57 \%$ of $\mathrm{P}$ in the Lake Kinneret water column stock exists as suspended particles (Plankton, Detritus) and $43 \%$ in dissolved forms. Moreover, in the top layer $(1 \mathrm{~cm})$ of the bottom sediments, there is a stock of $900 \mathrm{t}$ and $700 \mathrm{t}$ of $\mathrm{N}$ and $\mathrm{P}$, respectively. The Lake Kinneret habitat was P-limited throughout the entire PE period. The reason is the high $\mathrm{pH}$ and formation of undissolved complexes of Phospho-Carbonates due to high $\mathrm{Ca}^{++}$content. Such a bio-geochemical background of biomass reduction by fish predation enhanced the significance of the function of zooplankton homeostatic capability. Incorporating information documented by Andersen and Hessen [16] for the Lake Kinneret biota compartments resulted in $\mathrm{P}$ content (\%) in zooplankton, total phytoplankton and non-phyrrhophyte of $15 \%, 13 \%$, and $4 \%$, respectively. The low $\mathrm{P}$ content in the preferred algal food source (4\% of total) relative to the high $\mathrm{P}$ content in the zooplankton stock (15\% of total) compartment indicates that $\mathrm{P}$ cycling by zooplankton is a significant non-algal source. Nishri [1] approximated equal stocks of particulate (PP) and dissolved (SP) Phosphorus in Lake Kinneret. Consequently, about $30 \%$ of the P standing stock is PP and $30 \%$ SP. The following changes in the ecosystem were observed during the PE: zooplankton reduction enhanced nano-phytoplankton growth rate and consequently increased biomass density and independent P stock. Consequently, it is suggested that the enhancement of $\mathrm{P}$ flux through zooplankton homeostatic recycling led to the appropriate supply of $P$ required by enhanced nano-phytoplankton. Available sources of additional P demands were likely detritus, Bacteria, and Protozoa. These were the dynamic results of maintaining a balanced pattern of the energy flow through existing channels of an ecosystem under quantitatively and not qualitatively, changed conditions. Nevertheless, those modifications also resulted in the partial transfer of $\mathrm{P}$ from the homeostatic zooplankton to the phytoplankton [19-21]. These shifts were followed by an independent event of Nitrogen decline in the Lake Kinneret suspended particles. These modifications resulted in an increase in the $\mathrm{P}$ content and a decline in the $\mathrm{N}$ content, and the TN/TP mass ratio was, therefore, decreased in the Lake Kinneret suspended particles, especially in the algal cells. The impact of homeostasis caused P excretion, which afterward enhanced Cyanobacteria (CE). Conclusively, despite the removal of about 25-30 ton of $\mathrm{P}$ through fish landings and water withdrawal (pumping), the partial transfer of $\mathrm{P}$ from zooplankton to phytoplankton compartment constitutes partial enrichment of the Lake Kinneret water by $\mathrm{P}$, and the prevention of zooplankton reduction is beneficial for the lake management aimed at water quality protection. The long-term (1969-mid-1990s) decline in zooplankton density in Lake Kinneret and the subsequent increase are shown in Figure 8. The enhancement of zooplankton densities in the mid-1990s could be attributed to the implementation of the recommended subsidized Bleak fishery ("Bleak Dilution Project", BDP), which continued for 6 years, when about 5500 tons of Bleaks were removed. The objective of the BDP was to reduce zooplankton predation and increase the grazing pressure on non-pyrrhophytes in order to improve the water quality. Nevertheless, such an objective might have been considered successful if the increase in zooplankton grazing pressure was accompanied by phosphorus decline, but the opposite occurred (Figure 11). Due to zooplankton enhancement as well as the high level of available phosphorus (Figure 11), algal biomass increased (Figure 12). Phosphorus availability were slightly improved as a result of continuous external and internal inputs [19-21]. Rachamim et al. [14] documented a drastic change in the Nitrogen content of zooplankton particles (PNz) and Phosphorus content of zooplankton particles (PPz) with water level (WL) fluctuations; these changes were lowest for high WL and highest for low WL. The same authors [14] suggested that a decline in zooplankton contribution to Epilimnetic Particulate P (PP) and Particulate Nitrogen Particles N (PN) during winter flood seasons could be attributed to the intensification in zooplankton predation by fish. Nevertheless, information about seasonal fish feeding habits in Lake Kinneret confirmed low rates of fish feeding in winter, probably in response to low temperatures. Tilapia are tropically originated and therefore exhibit the lowest activity in winter, which is the reproductive season of the Palaearcticoriginated Bleak fishes, accompanied by a reduction in feeding rates.

\section{Synopsis: Future Perspective of Zooplankton Research in Lake Kinneret}

This paper is an attempt at establishing the central status of the zooplankton compartment in the Lake Kinneret ecosystem structure. The build-up to the hypothesis is supposed to have grown from a data-driven infrastructure. The eco-structure research growth has three optional directive concepts: 1) pure and solid data (field and experimental sources) and consequent evaluation; 2) data-driven modeling; and 3) a combination of (1) and (2). Einstein opinion on Modeling was define as "Do it as simple as possible but not simpler". Moreover, as part of J. Lovelock's "Gaia Philosophy" attempted to disprove the claim that the Gaia hypothesis is not scientific because it is impossible to test it by controlled experiments. It is possible that models were advanced before observation and measurement. The present Lake Kinneret research is probably too close to the point where modeling comes before observation and measurement, and modeling is a threat to scientific foundation. Nature is always the final determinant and the hypothesis should be examined by observation and experiment as indicated by Lovelock. How do models of processes and phenomena relate to reality?

The history of Lake Kinneret research indicates two periods: Until the 2000s, the Lake Kinneret limnological data were collected and evaluated as solid information that was incorporated into an up-todate complex food web interaction eco-structure. Later on, modeling with future perspectives became a major aspect of the entire concept of scientific research in Lake Kinneret. In this paper, I have presented a combination of field data and experimental studies, besides the precaution of misleading results of modeling evaluation. 
Zooplankton is under two directive eco-forces: A) Cascading topdown pressure by zooplanktivore fishes, but invertebrate predation is negligible, and increase in the Bleak population in the lake was documented [22-25]; B) Bottom-up through nutrients controlling the available algal density and likely the zooplankton is significantly affected by temperature and temperature elevation due to climate change (Figure 14) [4,5] also supported the forceful impact on metabolic activity. This paper has focused on the relation between climate change and Zooplankton ecology. A consequence of zooplankton density significant change to climate change was not documented. Climate change conditions enhanced the decline in the TN/TP mass ratio (Figure 11) which favored Cyanobacteria and enhanced their density. The long-term reduction in zooplankton density between 1969 and the mid-1990s changed to moderate elevation due to the intensification of subsidized Bleak fishery; nano-phytoplankton biomass density increased as a result of stable and slightly higher Epilimnetic availability of Phosphorus. During 1970-2000 a slight Eutrophication development in the Lake Kinneret ecosystem was indicated due mostly to climate change. Phytoplankton assemblages were modified in Lake Kinneret and consequently, fish and zooplankton community structures were supposed to be modified as well. Whereas recent reports [1] confirmed the essential linkage between zooplanktivorous predation pressure by enhanced population resulted by low marketing, of Bleaks on zooplankton (Figures 13 and 14). Unfortunately, results of experimental data on prey preferential habits of predator Copepoda were not incorporated into the newly developed ecological models [13]. It has not been possible to arrive at a comparative conclusions because biomass information and methodological background were not published. Water level fluctuation has probably no direct influence on the pelagic zooplankton fauna. Nevertheless, an indirect impact has been confirmed when Heavy discharge accompanied by WL elevation of above $2 \mathrm{~cm}$ per day induced intensive Bleak reproduction accompanied by zooplankton suppression.

Gyllstrom and Hanson et al. (13 more authors) [23] carried out a study on the role of Climate Change in shaping zooplankton communities in shallow lakes. They [23] concluded that TP was found to be the most important predictor of zooplankton biomass and community structure and Climate Change the next most important predictor. They [23] also emphasized the optional impact of Climate Change through top-down regulation by fish, i.e. linkage between food-web dynamics and Climate Change. The zooplankton adaptation capability supported flexibility of their densities and composition in response to the phytoplankton modification. Independently, prediction of changes to lake fishery management might accelerate the shift in zooplankton body size composition [24] due to increase in Bleak population. The elimination of Bleak marketing intensified cascading top-down suppression. Nevertheless, not without minor temporary fluctuations of the zooplankton community structure and the unique central position of its status was unchanged.

\section{Acknowledgment}

This paper is a memorial tribute to Prof. Ramesh Gulati

\section{Ethical Statements}

The author confirm the following Ethical Statements included in this paper: No ethical malfunction; No plagiarisms; No conflict of interests.

\section{References}

1. LKDB (1970-2020) Lake Kinneret Date Base, Kinneret Limnological Laboratory, IOLR, Annual Reports

2. Gophen M (1992) Conclusive Multiannual Report on Zooplankton in Lake Kinneret Kinneret limnonological Laboratory IOLR 72.

3. Gophen M (2018) Book: Ecological Research in the Lake Kinneret and Hula Valley (Israel) Ecosystems. Scientific Research Publishing Inc. USA 336.

4. Gvirtzman H (2002) Israel Water Resources, Chapters in Hydrology and Environmental Sciences; Yad Ben-Zvi Press: Jerusalem, Israel, 2002; 287.(In Hebrew).

5. Givati AT, Guillaume D, Rosenfdeld, Paz D (2019) Climate change impacts on stream flow at the upper Jordan River based on an ensemble of regional climate models. Journal of Hydrology: Regional studies 21: 92-109.

6. Gophen M, Azoulay B (2002) The Trophic status of zooplankton communities in Lake Knneret (Israel), Verh. Internat. Verein. Limnol 28: 836-839.

7. Gophen M (1972) Zooplankton Distribution in Lake Kinneret (Israel) 1969-1970 Israel J. Zool 21: 17-27.

8. Easton J, Gophen M (2003) Diel variations in the vertical distribution of fish and plankton in Lake Kinneret: a 24-h study of ecological overlap. Hydrobiologia 491: 91-100.

9. Bruce LC, Hamilton D, Imberger J, Gal G, Gophen M, et al. (2006) A numerical simulation of the role of zooplanktonin C, N, and P, cycling in Lake Kinneret, Israel. Ecological Modelling 193: 412-436.

10. Gophen, M. 2016. Population Dynamics of Cyclopoid Copepods in Lake Kinneret (Israel) Open Journal of Modern Hydrology, 6, 212-221, .http://dx.doi.org/10.4236/ ojmh.2016.64017

11. Serruya C, Pollingher U, Gophen M (1980) Lake Kinneret Carbon Flow Pattern and ecosystem management. Archiv. fHyur drobiologie 88: 265-302.

12. Walline P, Pisanti S, Gophen M, Berman T (1993) The Ecosystem of Lake Kinneret, Israel, in: V. Christensen and D. Pauly (eds.), Trophic Models of aquatic ecosystems 103-109. Phillipines: ICLARM, Denmark: International council for the exploration of the sea, Denmark: Danida

13. Gal G, Skerianer M, Tanasova N (2013) Fluctuations in Water Level and the dynamics of zooplankton: A data driven modeling approach. Freshwater Biolgy 58: 800-816.

14. Gophen M (1977) Food and Feeding Habits of Mesocyclops leuckarti (Claus) in Lake Kinneret (Israel). Freshwat. Biol 7: 513-518

15. Gophen M (1978) Chapter: Zooplankton, in: Lake Kinneret Monographiae Biologicae, Vol. 32.Dr. Junk bv Publishers The Hauge-Boston-London 1978 (C. Serruya ed.) 299-311.

16. Gophen M (1981) The Metabolism of Adult Mesocyclops leuckarti Populations in Lake Kinneret (Israel) During 1969-1978. Verh. Int. Verein. Limnol 21: 1568-1572.

17. Rachamin T, Stambler N, Zohari T, Berman-Frank I (2010) Zooplankton contribution to the particulate $\mathrm{N}$ and $\mathrm{P}$ in Lake Kinneret, Israel., under changing water levels. Hydrobiologia 655: 121-135.

18. Serruya C (ed.). (1978) Lake Kinneret Monographiae Biologicae, Vol. 32, Dr W. Junk Publishers The Hague-Boston-London, 501.

19. Andersen T, Hassen DO (1991) Carbon, Nitrogen, and Phosphorus content of Freshwater Zooplankton. Limnol. Oceanogr 36: 807-814.

20. Hessen DO (1992) Nutrient element limitation of zooplankton production. Am. Nat 140: 799-814.

21. Sterner RW (1990) The ratio of Nitrogen to Phosphorus resupplied by herbivores. zooplankton and algal competitive arena. The Am. Nat 136: 209-229. 
22. Sterner RW, Smith RF (1993) Clearance ingestion, and release of $N$ and P by Daphnia pulex feeding on Scenedesmus acutus of varying quality. Bull. Mar. Sci 53: 228-239.

23. Sterner RW, Elser JJ, Hessn DO (1992) Stochiometric relationships among producers, consumers, and nutrient cycling in pelagic ecosystems. Biogeochemistry 17: $49-67$
24. Watanabe $\mathrm{Y}$ (1990) C:N:P ratios of size fractionated seston and planktonic organisms in various trophic levels. Vererh. Internat.Verein. Limnol 24: 195-199.

25. Makler V, Hipsey MR, Zohary T, Carmel Y, Gal G (2017) Intraguild predation dynamics in a lake ecosystem based on a coupled Hydrodynamic-Ecological model: The example of Lake Kinneret (Israel). MDPI Biology 6: 22.

\section{Citation:}

Moshe Gophen (2021) Zooplankton Research in Lake Kinneret: A Review. Aquac Fish Stud Volume 3(4): 1-16. 